\title{
Color degradation kinetics in low-calorie strawberry and guava jellies
}

\author{
Cinética de degradação de cor em geleias light de morango e de goiaba
}

\author{
Silvia Cristina Sobottka Rolim de MOURA ${ }^{1 *}$, Patrícia PRATI ${ }^{2}$, Fernanda Zaratini VISSOTTO ${ }^{3}$, \\ Rita de Cássia Salvucci Celeste ORMENESE ${ }^{4}$, Marina dos Santos RAFACHO ${ }^{5}$
}

\begin{abstract}
The purpose of this study was to follow-up color changes in low-calorie strawberry and guava jellies during storage. To this end, one formulation of each flavor was prepared varying the application of hydrocolloids (pectin and modified starch). The jellies were studied regarding $\mathrm{pH}$, soluble solids, water activity and syneresis. In order to follow-up color changes, the samples remained stored for 180 days in chambers with controlled temperatures of $10{ }^{\circ} \mathrm{C}$ (control) and $25^{\circ} \mathrm{C}$ (commercial), and color instrumental analyses $\left(\mathrm{L}^{*}, \mathrm{a}^{*}\right.$, and $\left.\mathrm{b}^{*}\right)$ were performed every 30 days. Arrhenius model was applied to reaction speeds $(\mathrm{k})$ at different temperatures, where light strawberry and guava jellies showed greater color changes when stored at $25^{\circ} \mathrm{C}$ compared to the samples stored at $10^{\circ} \mathrm{C}$. Activation energy values between 13 and $15 \mathrm{kcal}_{\text {.mol }}^{-1}$ and $\mathrm{Q}_{10}$ values between 2.1 and 2.3 were obtained for light strawberry jelly and light guava jelly, respectively. Therefore, it was concluded that, with respect to color changes, every $10^{\circ} \mathrm{C}$ temperature increase reduces light jellies shelf-life by half.

Keywords: low-calorie sweets; kinetic study; color alterations.
\end{abstract}

\section{Resumo}

O objetivo do estudo foi o acompanhamento das alterações de cor em geleias de morango e goiaba light, durante a estocagem. Para o estudo, uma formulação de cada sabor foi preparada, variando a aplicação de hidrocoloides (pectina e amido modificado). As geleias foram caracterizadas quanto ao $\mathrm{pH}$, sólidos solúveis, atividade de água e sinérese. Para acompanhamento das alterações de cor, as amostras permaneceram armazenadas durante 180 dias em câmaras com temperaturas controladas de $10^{\circ} \mathrm{C}$ (controle) e $25^{\circ} \mathrm{C}$ (comercial) e, a cada 30 dias, foram realizadas análises instrumentais de cor $\left(\mathrm{L}^{*}, \mathrm{a}^{*} \mathrm{e} \mathrm{b}^{\star}\right)$. O modelo de Arrhenius foi aplicado às velocidades de reação $(\mathrm{k})$, nas diferentes temperaturas, mostrando que as geleias de morango e goiaba light apresentaram maiores alterações quando armazenadas na temperatura de $25^{\circ} \mathrm{C}$, quando comparadas com as amostras armazenadas a $10^{\circ} \mathrm{C}$. Foram obtidos valores de energia de ativação entre 13 e

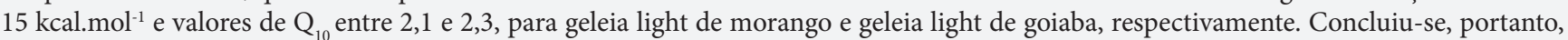
que, em termos de alterações de cor, a cada $10^{\circ} \mathrm{C}$ de aumento de temperatura a vida de prateleira das geleias light foi reduzida pela metade. Palavras-chave: doce light; estudo cinético; alterações de cor.

\section{Introduction}

The world is perceived by human beings through their senses, from which sight is the most pronounced one. Visual impact does not involve objects form and aspect only, but also their color. In food industry, color constitutes an important parameter applied to quality control, since acceptance or rejection of a given food occurs mainly through human eyes (TORREZAN et al., 2000).

Fruit species have different types of pigment which may somehow influence the resistance to color degradation. Strawberry has anthocyanin pigment, and its stability may be affected by other components of the fruit, such as ascorbic acid and phenolic components (MOURA et al., 2001). Regarding guava pulp, the color varies from yellow to red as a result of the presence of carotenoids ( $\beta$-carotene and lycopene) (TORREZAN et al., 2000). Process conditions and storage period also influence color deterioration of products containing anthocyanin and carotenoids.

Anthocyanin stability in spinach fruit strata (Basella rubra L.) in relation to degradation factors such as light, temperature and $\mathrm{pH}$, acting separately or jointly, was studied by Ozela, Stringheta and Chauca (2007). The authors concluded that pigments extracted from fruit are more stable under $\mathrm{pH} 5$ and $\mathrm{pH} 6$. Moreover, they verified that temperature increase and light presence affect pigment stability. Degradation reaction followed first order, with half-life period from $2\left(40^{\circ} \mathrm{C}\right)$ to 6 hours $\left(60^{\circ} \mathrm{C}\right)$.

Ferreira (2001) conducted an $\alpha$-carotene, $\beta$-carotene, lutein, and lycopene degradation kinetics study in model systems of low moisture content (corn starch, potato starch and microcrystalline cellulose) and aqueous at room temperature, both in the presence of light and in the dark. The results showed

\footnotetext{
Received 6/1/2010

Accepted 5/6/2010 (004613)

${ }^{1}$ Centro Tecnologia de Frutas e Hortaliças - FRUTHOTEC, Instituto de Tecnologia de Alimentos - ITAL, CEP 13070-178, Campinas, SP, Brasil, e-mail: smoura@ital.sp.gov.br

2 Apta Regional (Pólo Centro Sul), CEP 13412-050, Piracicaba, SP, Brasil

${ }^{3}$ Centro de Ciência e Qualidade dos Alimentos - CCQA, Instituto de Tecnologia de Alimentos - ITAL, CEP 13070-178, Campinas, SP, Brasil

${ }^{4}$ Centro de Tecnologia de Cereais e Chocolates - CEREAL CHOCOTEC, Instituto de Tecnologia de Alimentos - ITAL, CEP 13070-178, Campinas, SP, Brasil

${ }^{5}$ Faculdade de Engenharia de Alimentos, Universidade de Campinas - UNICAMP, CEP 13083862, Campinas, SP, Brasil

${ }^{*}$ Corresponding author
} 
predominance of first order kinetics model. In the dark, guava lycopene and $\beta$-carotene demonstrated lower degradation rates. Light exhibited prominent effect on carotenoids degradation in model systems and lyophilized food.

$1^{\text {st }}$ order reaction is that in which conversion speed depends on reagents concentration as shown below. Thus, for a reaction such as:

$$
\mathrm{A}+\mathrm{O}_{2} \rightarrow \text { A oxidized }
$$

Where reagent oxygen is not limited by diffusion, we will have Equation 1:

$\ln \left(\frac{C_{A}}{C_{A 0}}\right)=-k \times t$

$C_{A}=C_{A 0} \times \exp (-k \times t)$

By integrating them, we have Equation 2:

$-r_{A}=\frac{-d C_{A}}{d t}=k \times C_{A}$

$\frac{d C_{A}}{C_{A}}=-k \times d t$

Consequently, every time the decrease or increase of a reagent concentration is plotted on a monologarithmic scale in view of reaction time and a straight line is obtained, a $1^{\text {st }}$ order reaction is being studied. A slope of straight line drawn represents constant reaction speeds $(\mathrm{k})$.

Several authors have used color parameters $\left(L^{*}, a^{*}, b^{*}\right)$ and sensorial evaluations to establish the shelf-life of fruit products (JAYARAMAN, 1998; NEGRETE, 2001; MOURA et al., 2001, 2007; NACHTIGALL et al., 2004). The results obtained have demonstrated that fruit samples may suffer color and taste variation when stored at room temperature.

The demand for low-calorie food has stimulated the use of fruits as ingredients, since it allows for products with low caloric value and characteristics similar to conventional food (CAMPOS; CÂNDIDO, 1995). The low-calorie products market has noticeably increased, incited by a great number of consumers concerned about their health (SALGADO, 2001).

According to the Ordinance of 'Secretaria de Vigilância em Saúde do Ministério da Saúde' - SVS/MS [Health Surveillance Department of the Ministry of Health], Brazil, no. 27 of 01/13/98, "light" means a statement of a nutritional property of the product meaning a reduction in a given nutrient or caloric value content. Nevertheless, it is required that this reduction be of at least $25 \%$ compared to the conventional value so that the product be considered as "light" (FREITAS, 2005).

In order to develop products with reduction of sucrose, substituents (polysaccharides) must have certain attributes, such as commercial availability, chemical compatibility with food constituents, easy solubility, chemical and thermal stability, as well as, but not limited to, the exemption of toxicity and unusual flavors (TORREZAN et al., 2000).
With this premise, the purpose of this research was to study the low-calorie ("light") strawberry and guava jellies varying the application of hydrocolloids and assessing color stability products over time.

\section{Materials and methods}

Strawberry and guava jelly samples were elaborated in pilot scale, using a steam jacketed tank, with stirring, to the atmospheric pressure. The process comprises the following: formulation (fruit pulp, sucrose, glucose, pectin), concentration, addition of citric acid and potassium sorbate, hot filling, closure, flasks reversal, cooling, and storage.

Sample formulations had $60 \%$ of pulp, $23 \%$ of glucose (Excell 1040), $13.3 \%$ of sucrose, $0.2 \%$ of citric acid, and $0.05 \%$ of potassium sorbate. The hydrocolloids applied were:

- Strawberry: 1\% Pectin (8003) - CpKelco, and 0.8\% Modified starch (Snow-Flake 6704) - Corn Products;

- Guava: 1\% Pectin (8003) - CpKelco;

The choice of hydrocolloid type and the percentage of application were defined in preliminary studies (FEFIM et al., 2006; MOURA et al., 2006) based on manufacturer's information, texture and rheological behavior analyses initially conducted for standard solutions and for jellies thereafter.

Product end point was obtained by soluble solid contents of $40^{\circ} \mathrm{Brix}$, through a refractometer. Hot filling (above $85^{\circ} \mathrm{C}$ ) was performed in $267 \mathrm{~mL}$-glass flasks and closing was performed with metal lug closures (type ARJEK BR-1 63) with four clips (Rojek Ltda.) and flasks reversal for around 3 minutes. At first, cooling was performed in water bath $60^{\circ} \mathrm{C}$, and after a few minutes cold water flow was initiated in the tank, avoiding a sudden thermal shock and possible glass breaking. Product cooling was conducted in a tank with running water until the temperature of $38-40{ }^{\circ} \mathrm{C}$ was reached. This technique is recommended so packages can dry naturally and faster, avoiding rust formation in cans and glassware closures.

One batch of each formulation was obtained i.e. two processes were made and in each one of them, 50 flasks were gotten and equally distributed in chambers with controlled temperatures of $10^{\circ} \mathrm{C}$ (control) and $25^{\circ} \mathrm{C}$ (commercial) in the absence of light.

In order to study the samples, physical-chemical evaluations of pH (INSTITUTO ADOLFO LUTZ, 1985), soluble solids (INSTITUTO ADOLFO LUTZ, 1985), water activity (DECAGON CX-2), and syneresis (BAIDÓN et al., 1987) were performed.

Instrumental color was followed-up in colorimeter Color Eye 2020 Plus, Macbeth (Newburgh, USA), with software COMCOR 1500Plus, illuminant D65 (daylight), observation angle of $10^{\circ}$, for a period of 180 days. The results were presented using CIELab system (parameters $L^{*}, a^{*}, b^{*}$ ). For statistical analysis, software SAS (STATISTICAL ANALISYS SYSTEM INSTITUTE, 1993) was used with an Analysis of Variance (Anova) and means test (Tukey) at $\mathrm{p}<0.05$. 
Total difference of color $(\Delta \mathrm{E})$ was calculated as per Equation 3, where: $\Delta$ is the difference between each color parameter of initial sample (time zero) and sample stored:

$\Delta \mathrm{E}=\left[(\Delta \mathrm{L})^{2}+(\Delta \mathrm{a})^{2}+(\Delta \mathrm{b})^{2}\right]^{1 / 2}$

Analyses were performed every 30 days (triplicate) for both temperatures $\left(10^{\circ} \mathrm{C}\right.$ and $\left.25^{\circ} \mathrm{C}\right)$ for 180 days, and the results were assessed for order of degradation reaction, reaction velocities ( $\mathrm{k}), \mathrm{Q}_{10}, \mathrm{Ea}$, (activation energy), and VP (shelf-life) (TEIXEIRA NETO; VITALI; MOURA, 2004).

In order to determine reaction order and its constant of velocity, color parameters versus time were plotted in linear graphs (order zero), logarithmic graphs (first order), and graphs of parameter inverse by time (second order), then a linear regression of such values was performed. Reaction follows the order of best regression adjustment (higher $\mathrm{r}^{2}$ ). The inclination achieved from linear regression of best adjustment for each temperature corresponds to the $\mathrm{k}$ values (velocities of reaction).

$\mathrm{Q}_{10}$, Ea, (activation energy) and VP (shelf-life) values were determined using Equations 4 and 5.

$$
Q_{\Delta T}=\frac{k_{T 2}}{k_{T 1}}=Q_{10}^{\frac{\Delta T}{10}}=\frac{V P_{T 1}}{V P_{T 2}}
$$

Where $\mathrm{T} 2=25^{\circ} \mathrm{C}$ and $\mathrm{T} 1=10^{\circ} \mathrm{C}$

$$
E a=0,46 \times T^{2} \times \log Q_{10}
$$

Where $\mathrm{T}=298 \mathrm{~K}$

\section{Results and discussion}

\subsection{Physical-chemical characterization of samples}

Analyses of $\mathrm{pH}$, soluble solids, Aw, and syneresis were conducted; they are shown in Table 1.

In general, different types of starch did not influence $\mathrm{pH}$ of low-calorie jelly; however, they evidenced $\mathrm{pH}$ values approximately $10 \%$ above conventional jelly, probably due to the process (NACHTIGALL et al., 2004).

The results of soluble solids of the samples elaborated in pilot scale were slightly higher than the expected values $\left(40^{\circ} \mathrm{Brix}\right)$. This was due to the difficulty in controlling the process in steam jacketed tanks to the atmospheric pressure.

The Aw values found were raised, confirming the need to use preservatives in low-calorie jellies. Traditional jellies (55-60 ${ }^{\circ} \mathrm{Brix}$ ) have Aw values close to 0.78 . According to Jardim (2004), most bacteria do not grow in Aa below 0.91 and mold in Aa below 0.8. Foods considered semi-perishable are within 0.88 and $0.96 \mathrm{Aw}$ range, where a large microbial deterioration can still be observed. Thus, foods need to be processed or cooled down so that they can be consumed for a longer period. Light jellies are within the upper limit of this range, needing pasteurization and addition of preservatives in order to be safely kept at room temperature.

\subsection{Follow-up of instrumental color of low-calorie strawberry and guava jellies}

\section{Strawberry Jelly}

Table 2 shows the results for $\mathrm{L}^{*}, \mathrm{a}^{*}$, and $\mathrm{b}^{*}$ parameters for strawberry jelly samples due to storage period.

In samples stored at $25^{\circ} \mathrm{C}$, a tendency of darkening ( $\mathrm{L}^{*}$ diminishing) and presenting a red color $\left(+\mathrm{a}^{\star}\right)$ with lower intensity was verified for strawberry jelly during the period of 180 days. Regarding the yellow color $(+b)$, a significant reduction in the first 30 days of storage both $10^{\circ} \mathrm{C}$ and $25^{\circ} \mathrm{C}$ was verified, as well as a tendency of maintaining the color during the remaining time of assessment.

Strawberry jelly stored at $25^{\circ} \mathrm{C}$ tends to present luminosity $\left(\mathrm{L}^{*}\right)$ and yellow color $(+\mathrm{b})$ similar to product stored at $10{ }^{\circ} \mathrm{C}$, and a lower intensity of red color $\left(+\mathrm{a}^{\star}\right)$ as from the second month of evaluation.

Products containing anthocyanins, as strawberry jelly, are susceptible to color deterioration during processing and storage as a result of the combined effects of anthocyanin degradation and dark pigments formation (SKREDE et al., 1992). A similar effect occurred in a trial developed by Miguel, Albertini and Spotp (2009), when strawberry marmalade degradation kinetics was studied. According to the author, ascorbic acid oxidation may also occur through anaerobic pathway leading to the formation of hydroxymethylfurfural and furfural, respectively, which, in turn, generate melanoidines that cause darkening, as observed in the Maillard reaction. The anaerobic phase occurs during storage and tends to be more intense as temperature increases. In addition to non-enzymatic darkening (Maillard), the emergence of an unnatural taste in products, resulting in loss of quality and shelf-life reduction, is also noted.

Regarding the color attribute, low-calorie jellies usually have a less intense color than conventional formulations (NACHTIGALL et al., 2004). This is due to the application of BTM pectin, which leads to a reduction in the products coloring. However, in Nachtigall et al. (2004), a negative influence of adding starches on the coloring of blackberry jelly samples, where main pigment is anthocyanin, was not verified, and the same was observed for strawberry jelly. Every formulation had a stable behavior for 90 days, and coloring loss during storage was not observed.

The results obtained by Soler et al. (1998) in the analysis of guava paste (carotenoid pigment) luminosity $\left(\mathrm{L}^{*}\right)$ showed that values from different low-calorie products for this parameter were higher than the ones for the standard sample (commercial). Those results were consistent, since standard sample had a soluble solids content of $68^{\circ} \mathrm{Brix}$, whereas low-calorie samples had contents ranging from $45-54^{\circ} \mathrm{Brix}$.

With the purpose to evaluate the reaction kinetics of color parameters for strawberry jelly, the order of color parameters reaction was studied and the reaction velocity was determined. $\mathrm{Q}_{10}$ value (Equation 4) and activation energy (Equation 5) were also established for each parameter (Table 3). 
Table 1. Means and respective deviations of soluble solids, Aw, and syneresis parameters of low-calorie strawberry and guava jelly samples.

\begin{tabular}{ccccc}
\hline Jelly & ${ }^{\circ}$ Brix & $\mathrm{pH}$ & Aw & Syneresis $(\mathrm{cm})$ \\
\hline Strawberry & $43.2 \pm 0.2$ & $3.56 \pm 0.01$ & $0.957 \pm 0.001$ & 0.0 \\
Guava & $42.6 \pm 0.1$ & $4.19 \pm 0.02$ & $0.955 \pm 0.002$ & 0.0 \\
\hline
\end{tabular}

Table 2. Parameters $\mathrm{L}^{\star}, \mathrm{a}^{\star}$, and $\mathrm{b}^{\star}$ due to storage period for strawberry jelly samples.

\begin{tabular}{|c|c|c|c|}
\hline \multicolumn{4}{|c|}{ Parameter $L^{*}$} \\
\hline Time (days) & Temperature $\left(10^{\circ} \mathrm{C}\right)$ & Temperature $\left(25^{\circ} \mathrm{C}\right)$ & D.M.S. \\
\hline 0 & $19.46 \pm 0.61^{\mathrm{A}}$ & $19.46 \pm 0.61^{\mathrm{A}}$ & - \\
\hline 30 & $18.46 \pm 0.41^{\mathrm{aBC}}$ & $18.18 \pm 0.39^{\mathrm{aBC}}$ & 0.909 \\
\hline 60 & $17.97 \pm 0.08^{\mathrm{aC}}$ & $17.99 \pm 0.33^{\mathrm{aBC}}$ & 0.539 \\
\hline 90 & $19.36 \pm 0.17^{\mathrm{aA}}$ & $18.42 \pm 0.35^{\mathrm{bABC}}$ & 0.621 \\
\hline 120 & $18.90 \pm 0.03^{\mathrm{aAB}}$ & $18.86 \pm 0.04^{\mathrm{aAB}}$ & 0.075 \\
\hline 150 & $18.10 \pm 0.15^{\mathrm{aBC}}$ & $17.47 \pm 0.51^{\mathrm{aC}}$ & 0.857 \\
\hline 180 & $18.23 \pm 0.09^{\mathrm{aBC}}$ & $17.44 \pm 0.06^{\mathrm{bC}}$ & 0.173 \\
\hline D.M.S. & 0.822 & 1.063 & \\
\hline \multicolumn{4}{|c|}{ Parameter $\mathrm{a}^{*}$} \\
\hline 0 & $22.02 \pm 0.48^{\mathrm{A}}$ & $22.02 \pm 0.48^{\mathrm{A}}$ & - \\
\hline 30 & $19.97 \pm 0.99^{\mathrm{aB}}$ & $18.14 \pm 0.74^{\mathrm{aB}}$ & 1.977 \\
\hline 60 & $17.42 \pm 0.43^{\mathrm{aD}}$ & $16.26 \pm 0.47^{\mathrm{bC}}$ & 1.017 \\
\hline 90 & $19.48 \pm 0.06^{\mathrm{aBC}}$ & $15.56 \pm 0.48^{\mathrm{bC}}$ & 0.779 \\
\hline 120 & $18.23 \pm 0.21^{\mathrm{aCD}}$ & $15.25 \pm 0.35^{\mathrm{bCD}}$ & 0.653 \\
\hline 150 & $17.82 \pm 0.12^{\mathrm{aD}}$ & $13.97 \pm 0.67^{\mathrm{bDE}}$ & 1.098 \\
\hline 180 & $17.59 \pm 0.04^{\mathrm{aD}}$ & $13.29 \pm 0.22^{\mathrm{bE}}$ & 0.356 \\
\hline D.M.S. & 1.269 & 1.435 & \\
\hline \multicolumn{4}{|c|}{ Parameter $b^{*}$} \\
\hline 0 & $12.58 \pm 0.33^{\mathrm{A}}$ & $12.58 \pm 0.33^{\mathrm{A}}$ & - \\
\hline 30 & $11.37 \pm 0.52^{\mathrm{aB}}$ & $11.24 \pm 0.54^{\mathrm{aB}}$ & 1.200 \\
\hline 60 & $9.77 \pm 0.23^{\mathrm{bC}}$ & $10.88 \pm 0.34^{\mathrm{aB}}$ & 0.661 \\
\hline 90 & $11.62 \pm 0.21^{\mathrm{aB}}$ & $11.07 \pm 0.48^{\mathrm{aB}}$ & 0.840 \\
\hline 120 & $11.13 \pm 0.11^{\mathrm{bB}}$ & $11.72 \pm 0.21^{\mathrm{aAB}}$ & 0.385 \\
\hline 150 & $10.99 \pm 0.12^{\mathrm{aB}}$ & $10.80 \pm 0.40^{\mathrm{aB}}$ & 0.663 \\
\hline 180 & $10.93 \pm 0.03^{\mathrm{aB}}$ & $10.73 \pm 0.03^{\mathrm{bB}}$ & 0.061 \\
\hline D.M.S. & 0.746 & 1.029 & \\
\hline
\end{tabular}

Results expressed as mean \pm standard deviation of 3 determinations. D.M.S. Less significant difference at $p<0.05$ as Tukey's test. In each line, means followed by equal small letters are not significantly different at $\mathrm{p}<0.05$. In each column, means followed by equal capital letters are not significantly different at $\mathrm{p}<0.05$

Table 3. Kinetics parameters for color change of strawberry jelly.

\begin{tabular}{|c|c|c|}
\hline Kinetic parameter & Temperature $\left({ }^{\circ} \mathrm{C}\right)$ & Temperature $\left({ }^{\circ} \mathrm{C}\right)$ \\
\hline $\mathrm{L}^{*}$ & 10 & 25 \\
\hline Order & First & First \\
\hline $\mathrm{k}\left(\right.$ day $\left.^{-1}\right)$ & -0.0002 & -0.0004 \\
\hline \multicolumn{3}{|l|}{$a^{*}$} \\
\hline Order & First & First \\
\hline $\mathrm{k}\left(\right.$ day $\left.^{-1}\right)$ & -0.001 & -0.0025 \\
\hline \multicolumn{3}{|l|}{$\mathrm{b}^{*}$} \\
\hline Order & First & First \\
\hline $\mathrm{k}\left(\right.$ day $\left.^{-1}\right)$ & -0.0004 & -0.0006 \\
\hline \multicolumn{3}{|l|}{$\Delta \mathrm{E}$} \\
\hline Order & Zero & Zero \\
\hline $\mathrm{k}\left(\right.$ day $\left.^{-1}\right)$ & 0.0097 & 0.0298 \\
\hline $\mathrm{Q}_{10}$ & & 2.11 \\
\hline $\mathrm{Ea}(\mathrm{cal} / \mathrm{gmol})$ & & 13.266 .22 \\
\hline
\end{tabular}

Color changes with respect to $\mathrm{L}^{*}, \mathrm{a}^{\star}$, and $\mathrm{b}^{*}$ in strawberry jellies followed a $1^{\text {st }}$ order reaction, and total color change $(\Delta \mathrm{E})$ followed a zero order.

First order reactions are, by far, the most common and most well-studied ones in food. Pigment destruction reactions during processing and storage are among those which follow this order of reaction (TEIXEIRA NETO; VITALI; MOURA, 2004).

Anthocyanins degradation due to time followed a first order reaction, which complies with previously conducted researches (CEMEROGLU; VELIOGLU; ISIK, 1994; GIUSTI; WROLSTAD, 1996; MOURA et al., 2001; PROVENZI et al., 2006; OZELA; STRINGHETA; CHAUCA, 2007).

The activation energy values achieved are within 10 to $30 \mathrm{kcal}^{\mathrm{mol}}{ }^{-1}$ range, as mentioned by Lund (1979), for food color. 
The $\mathrm{Q}_{10}$ value achieved due to reaction velocity of $\Delta \mathrm{E}$ was approximately 2.0 , meaning that reactions are accelerated by temperature, that is, each $10{ }^{\circ} \mathrm{C}$ temperature increase at this range doubles the speed of reactions.

In $\mathrm{Q}_{10}=\mathrm{VP}(\mathrm{T}-10) / \mathrm{VP}(\mathrm{T})$, each increase of $10^{\circ} \mathrm{C}$ in storage temperature of strawberry jelly divides shelf-life time by 2.0.

\section{Guava Jelly}

Table 4 shows the results of parameters $\mathrm{L}^{*}, \mathrm{a}^{*}$, and $\mathrm{b}^{*}$ for guava jelly samples due to storage period.

Both at $10{ }^{\circ} \mathrm{C}$ and $25{ }^{\circ} \mathrm{C}$, guava jelly sample showed a tendency of a low-calorie darkening ( $\mathrm{L}^{*}$ diminishing) during storage period.

Compared to sample stored at both studied temperatures, it was verified that as from the $30^{\text {th }}$ day, the product stored at $25^{\circ} \mathrm{C}$ was significantly $(\mathrm{p}<0.05)$ darker than the product stored at $10{ }^{\circ} \mathrm{C}$ in practically every evaluation time. In general, there was no significant difference in red and yellow colors between samples at $10^{\circ} \mathrm{C}$ and $25^{\circ} \mathrm{C}$.

Tasca (2007) developed a study to measure guava cv. Paluma color and its processed products through CIELAB system, as well as to relate them with the total carotenoids contents. The authors concluded that the contents of total carotenoids showed good correlation with the parameters $L^{*}, a^{*}, b^{*}$ and Chroma for guava cv. Paluma and good correlation with all parameters evaluated for the pulp of guava. For guava marmalade, only the hue parameter and the $a^{*} / b^{*}$ and $\left(a^{*} / b^{*}\right) 2$ reasons showed good correlation with the level of total carotenoids, due to the fact that in the process to obtain guava marmalade occurs the formation of sugar caramel with dark compounds that will also contribute to the final color of guava marmalade.

With the purpose to evaluate the reaction kinetics of color parameters for guava jelly, the order of color parameters reaction was studied and the reaction velocity was determined. $\mathrm{Q}_{10}$ value (Equation 4) and activation energy (Equation 5) were also established for each parameter (Table 5).

Color changes with respect to $\mathrm{L}^{\star}, \mathrm{a}^{\star}$, and $\mathrm{b}^{*}$ in guava jellies followed $1^{\text {st }}$ order reaction, and total color change $(\Delta \mathrm{E})$ followed a zero order.

Carotenoids degradation due to time followed a first order reaction, which is consistent with previously conducted researches (FERREIRA, 2001; ROSSO, 2006).

The $\mathrm{Q}_{10}$ mean value obtained was approximately 2.3. In $\mathrm{Q}_{10}=\mathrm{VP}(\mathrm{T}-10) / \mathrm{VP}(\mathrm{T})$, each increase of $10{ }^{\circ} \mathrm{C}$ in storage temperature of guava sample divides shelf-life time by 2.3 .

Table 4. Parameters $L^{*}, a^{*}$, and $b^{\star}$ due to storage period for guava jelly samples.

\begin{tabular}{|c|c|c|c|}
\hline \multicolumn{4}{|c|}{ Parameter $\mathrm{L}^{*}$} \\
\hline Time (days) & Temperature $\left(10^{\circ} \mathrm{C}\right)$ & Temperature $\left(25^{\circ} \mathrm{C}\right)$ & D.M.S \\
\hline 0 & $33.23 \pm 0.32^{\mathrm{AB}}$ & $33.23 \pm 0.32^{\mathrm{A}}$ & - \\
\hline 30 & $33.30 \pm 0.03^{\mathrm{aA}}$ & $32.77 \pm 0.11^{\mathrm{bA}}$ & 0.185 \\
\hline 60 & $33.02 \pm 0.13^{\mathrm{aABC}}$ & $32.14 \pm 0.22^{\mathrm{bAB}}$ & 0.407 \\
\hline 90 & $32.76 \pm 0.02^{\mathrm{aBCD}}$ & $30.56 \pm 0.55^{\mathrm{bB}}$ & 0.887 \\
\hline 120 & $32.74 \pm 0.12^{\mathrm{aCD}}$ & $32.14 \pm 0.06^{\mathrm{bAB}}$ & 0.210 \\
\hline 150 & $32.31 \pm 0.23^{\mathrm{aDE}}$ & $30.73 \pm 0.92^{\mathrm{bB}}$ & 1.52 \\
\hline 180 & $32.18 \pm 0.13^{\mathrm{aE}}$ & $30.71 \pm 1.48^{\mathrm{aB}}$ & 2.39 \\
\hline D.M.S. & 0.477 & 1.979 & - \\
\hline \multicolumn{4}{|c|}{ Parameter $\mathrm{a}^{*}$} \\
\hline 0 & $15.44 \pm 0.14^{\mathrm{B}}$ & $15.44 \pm 0.14^{\mathrm{BC}}$ & - \\
\hline 30 & $16.24 \pm 0.11^{\mathrm{aA}}$ & $16.17 \pm 0.14^{\mathrm{aAB}}$ & 0.285 \\
\hline 60 & $15.31 \pm 0.10^{\mathrm{aBC}}$ & $15.25 \pm 0.26^{\mathrm{aC}}$ & 0.450 \\
\hline 90 & $16.27 \pm 0.14^{\mathrm{aA}}$ & $15.81 \pm 0.06^{\mathrm{bABC}}$ & 0.245 \\
\hline 120 & $14.73 \pm 0.44^{\mathrm{bC}}$ & $16.29 \pm 0.03^{\mathrm{aA}}$ & 0.710 \\
\hline 150 & $15.66 \pm 0.27^{\mathrm{aAB}}$ & $15.92 \pm 0.32^{\mathrm{aABC}}$ & 0.672 \\
\hline 180 & $15.49 \pm 0.14^{\mathrm{aB}}$ & $16.09 \pm 0.62^{\mathrm{aAB}}$ & 1.012 \\
\hline D.M.S. & 0.623 & 0.814 & \\
\hline \multicolumn{4}{|c|}{ Parameter $b^{*}$} \\
\hline 0 & $25.39 \pm 0.03^{\mathrm{BC}}$ & $25.39 \pm 0.03^{\mathrm{A}}$ & - \\
\hline 30 & $25.56 \pm 0.13^{\mathrm{aAB}}$ & $25.63 \pm 0.13^{\mathrm{aA}}$ & 0.292 \\
\hline 60 & $25.48 \pm 0.06^{\mathrm{aB}}$ & $25.37 \pm 0.36^{\mathrm{aA}}$ & 0.586 \\
\hline 90 & $25.81 \pm 0.02^{\mathrm{aA}}$ & $25.00 \pm 0.18^{\mathrm{bA}}$ & 0.296 \\
\hline 120 & $25.07 \pm 0.19^{\mathrm{bC}}$ & $26.07 \pm 0.10^{\mathrm{aA}}$ & 0.337 \\
\hline 150 & $25.32 \pm 0.11^{\mathrm{aBC}}$ & $24.92 \pm 0.50^{\mathrm{aA}}$ & 0.827 \\
\hline 180 & $25.10 \pm 0.17^{\mathrm{aC}}$ & $25.32 \pm 1.07^{\mathrm{aA}}$ & 1.737 \\
\hline D.M.S. & 0.329 & 1.329 & \\
\hline
\end{tabular}

Results expressed as mean \pm standard deviation of 3 determinations. D.M.S. Less significant difference at $\mathrm{p}<0.05$ as Tukey's test. In each line, means followed by equal small letters are not significantly different at $\mathrm{p}<0.05$. In each column, means followed by equal capital letters are not significantly different at $\mathrm{p}<0.05$. 
Table 5. Kinetics parameters for color change of guava jelly.

\begin{tabular}{|c|c|c|}
\hline Kinetic parameter & Temperature $\left({ }^{\circ} \mathrm{C}\right)$ & Temperature $\left({ }^{\circ} \mathrm{C}\right)$ \\
\hline $\mathrm{L}^{*}$ & 10 & 25 \\
\hline Order & First & First \\
\hline $\mathrm{k}\left(\right.$ day $\left.^{-1}\right)$ & -0.0002 & -0.0004 \\
\hline \multicolumn{3}{|l|}{$a^{*}$} \\
\hline Order & First & First \\
\hline $\mathrm{k}\left(\right.$ day $\left.^{-1}\right)$ & -0.0001 & 0.0002 \\
\hline \multicolumn{3}{|l|}{$b^{*}$} \\
\hline Order & First & First \\
\hline $\mathrm{k}\left(\right.$ day $\left.^{-1}\right)$ & $-8^{\star} 10^{-5}$ & $-4^{\star} 10^{-5}$ \\
\hline \multicolumn{3}{|l|}{$\Delta \mathrm{E}$} \\
\hline Order & Zero & Zero \\
\hline $\mathrm{k}\left(\right.$ day $\left.^{-1}\right)$ & 0.0031 & 0.0112 \\
\hline $\mathrm{Q}_{10}$ & & 2.35 \\
\hline $\mathrm{Ea}(\mathrm{cal} / \mathrm{gmol})$ & & 15.158 .06 \\
\hline
\end{tabular}

\section{Conclusions}

In study conditions, it was observed that color changes depend on the temperature and treatment period.

Low-calorie strawberry and guava jellies stored at temperature of $25^{\circ} \mathrm{C}$ have suffered bigger color changes than those stored at $10^{\circ} \mathrm{C}$.

Strawberry and guava jellies have become darker ( $\mathrm{L}^{*}$ diminishing) during the storage period of 180 days.

Based on the $\mathrm{Q}_{10}$ found, regarding color changes, every $10^{\circ} \mathrm{C}$ temperature increase reduces light jellies shelf-life by half.

\section{Acknowledgements}

The authors are grateful to CNPq for the granting of the scientific initiation studentship, to 'Supergelados Jundiaî' for providing the fruit pulps, and to 'CpKelco' and 'Corn Products' for the input supplying.

\section{References}

BAIDÓN, S. et al. Sineresis de los geles de agar y kappa-carragenato. Influencia de la adición de gomas de garrafin y guar. Revista de Agroquímica y Tecnología de Alimentos, v. 27, n. 4, p. 545-555, 1987

CAMPOS, A. M.; CÂNDIDO, L. M. B. Formulação e avaliação físico-química e reológica de geléias de baixo teor de sólidos solúveis com diferentes adoçantes e edulcorantes. Ciência e Tecnologia de Alimentos, v. 15, n. 3, p. 268-278, 1995.

CEMEROGLU, B.; VELIOGLU, S.; ISIK, S. Degradation kinetics of anthocyanins in sour cherry juice and concentrate. Journal of Food Science, v. 59, p. 1216-1218, 1994. http://dx.doi. org/10.1111/j.1365-2621.1994.tb14680.x

FEFIM, D. A. et al. Estudo do emprego de hidrocolóides em soluções modelo de geléias e doces cremosos light. In: SEMINÁRIO DE INICIAÇÃO CIENTÍFICA PIBIC CNPq-ITAL, 13., 2006, Campinas. Anais... Campinas: CNPq-ITAL, 2006. 1 CD-ROM.

FERREIRA, J. E. M. Cinética e fatores que influenciam na degradação de carotenóides em sistemas modelos e alimentos. 2001. $85 \mathrm{f}$.
Dissertação (Mestrado em Tecnologia de Alimentos)-Universidade Estadual de Campinas, Campinas, 2001.

FREITAS, S. M. L. Alimentos com alegação diet light: definições, legislação e orientações para consumo. São Paulo: Atheneu, 2005. $138 \mathrm{p}$.

GIUSTI, M. M.; WROLSTAD, R. E. Radish anthocyanin extract as a natural red colorant for Maraschino cherries. Journal of Food Science, v. 61, n. 4, p. 688-694, 1996. http://dx.doi. org/10.1111/j.1365-2621.1996.tb12182.x

INSTITUTO ADOLFO LUTZ. Normas analíticas do Instituto Adolfo Lutz. 3. ed. São Paulo: IAL, 1985. vol 1: Métodos químicos e físicos para análises de alimentos.

JAYARAMAN, K. S. Development of intermediate moisture tropical fruit and vegetable products-technological problems and prospects. In: SEOW, C. C.; TEMG, T. T.; QUAH, C. H. Food preservation by moisture control. Londres: Elsevier Applied Science, 1998. p. 175-198.

JARDIM, D. C. P. Reações de Transformação em Alimentos - influência da água. In: MOURA, S. C. S. R.; GERMER, S. P. M. Reações de Transformação e Vida-de-Prateleira de Alimentos Processados. 3. ed. Campinas: ITAL, 2004. cap. 2, p. 16-24.

LUND, D. B. Effect of commercial processing on nutrients. Food Technology, v. 33, n. 2, p. 28-35, 1979.

MigUEL, A. C. A.; AlBeRTINI, S.; SPOTP, M. H. F. Cinética da degradação de geleiada de morango. Ciência e Tecnologia de Alimentos, v. 29, n. 1, p. 142-147, 2009.

MOURA, S. C. S. R. et al. Cinética de degradação de polpas de morango. Brazilian Journal of Food Technology, v. 4, p. 115-121, 2001.

MOURA, S. C. S. R. et al. Propriedades reológicas de soluções modelo de geléias e doces em massa. In: CONGRESSO BRASILEIRO DE CIÊNCIA E TECNOLOGIA DE ALIMENTOS, 20., 2006, Campinas. Anais... Campinas, 2006. p. 1141. 1 CD-ROM.

MOURA, S. C. S. R. et al. Determinação da vida-de-prateleira de maçã-passa por testes acelerados. Ciência e Tecnologia de Alimentos, v. 27, n. 1, p. 141-148, 2007.

NACHTIGALL, A. M. et al. Geléias light de amora-preta . Boletim do CEPPA, v. 22, n. 2, p. 337-354, 2004.

NEGRETE, V. Desenvolvimento de processo a vácuo para geléia de acerola (Malpighia emarginata, Malpighia glabra). 2001. $92 \mathrm{f}$. Dissertação (Mestrado em Tecnologia de Alimentos)-Universidade Estadual de Campinas, Campinas, 2001.

OZELA, E. F.; STRINGHETA, P. C.; CHAUCA, M. C. Stability of anthocyanin in spinach vine (Basella rubra) fruits. Ciencia e Investigación Agrária, v. 34, n. 2, p. 115-120, 2007.

PROVENZI G. et al. Estabilidade de Antocianinas de Uvas Cabernet Sauvignon com $\beta$ - e $\gamma$-Ciclodextrinas, Brazilian Journal of Food Technology, v. 9, n. 3, p. 165-170, 2006.

ROSSO, V. V. Composição de carotenóides e antocianinas em acerola: estabilidade e atividade antioxidante em sistemas-modelo de extratos antociânicos de acerola e de açaí. 2006. 136 f. Tese (Doutorado em Ciências de Alimentos)-Universidade Estadual de Campinas, Campinas, 2006.

SALGADO, J. M. Adoçantes dietéticos: doçura que não vem da cana. Diário Popular, Saúde, p. 2-3, 4, 2001.

STATISTICAL ANALISYS SYSTEM INSTITUTE - SAS. SAS User's Guide: Statistics. Cary: SAS Inst., 1993.

SKREDE, G. et al. Color stability of strawberry and blackcurrant syrups. Journal of Food Science, v. 57, n. 1, p. 172-177, 1992. http://dx.doi. org/10.1111/j.1365-2621.1992.tb05449.x 
SOLER, M. P. et al. Aplicação de hidrocolóides na formulação de goiabada com baixo teor de açúcar. Boletim SBCTA, v. 32, n. 1, p. 30-34, 1998.

TASCA, A. P. W. Efeito do processamento industrial para obtenção de goiabada sobre os compostos antioxidantes e cor. 2007. $110 \mathrm{f}$. Dissertação (Mestrado em Ciências de Alimentos)-Universidade Estadual Paulista, Araraquara, 2007.
TEIXEIRA NETO, R. O.; VITALI, A. A.; MOURA, S. C. S. R. Introdução à Cinética de Reação em Alimentos. In: MOURA, S. C. S. R.; GERMER, S. P. M. Reações de Transformação e Vida-de-Prateleira de Alimentos Processados. 3. ed. Campinas: ITAL, 2004. cap. 3, p. 25-47.

TORREZAN, R. et al. Efeito da adição de ingredientes na cor de polpa de goiaba. Boletim do CEPPA, v. 18, n. 2, p. 209-220, 2000. 